\title{
Using ARC-D Toolkit for Measuring Community Resilience to Disasters
}

\author{
Muhammad Awfa Islam ${ }^{1}$, Musabber Ali Chisty 1,*(1), Abdullah Fuad ${ }^{2}$, Md. Mostafizur Rahman ${ }^{3}$, \\ Maliha Muhtasim ${ }^{1}$, Syeda Erena Alam Dola ${ }^{1}$, Fariha Jahin Biva ${ }^{1}$ and Nesar Ahmed Khan ${ }^{1}$
}

check for

updates

Citation: Islam, M.A.; Chisty, M.A.; Fuad, A.; Rahman, M.M.; Muhtasim, M.; Dola, S.E.A.; Biva, F.J; Khan, N.A Using ARC-D Toolkit for Measuring Community Resilience to Disasters. Sustainability 2022, 14, 1758. https:// doi.org/10.3390/su14031758

Academic Editors: Stefano Morelli, Veronica Pazzi and Mirko Francioni

Received: 24 December 2021

Accepted: 19 January 2022

Published: 3 February 2022

Publisher's Note: MDPI stays neutral with regard to jurisdictional claims in published maps and institutional affiliations.

Copyright: (C) 2022 by the authors. Licensee MDPI, Basel, Switzerland. This article is an open access article distributed under the terms and conditions of the Creative Commons Attribution (CC BY) license (https:// creativecommons.org/licenses/by/ $4.0 /)$.
1 Institute of Disaster Management and Vulnerability Studies, University of Dhaka, Dhaka 1000, Bangladesh; awfaislam@du.ac.bd (M.A.I.); maliha.muhtasim@gmail.com (M.M.); erenaalam@gmail.com (S.E.A.D.); farihajahin03@gmail.com (F.J.B.); arnob.k7715@gmail.com (N.A.K.)

2 Emergency Response Program, Caritas Bangladesh, Cox's Bazar Office, Dhaka 1217, Bangladesh; abdullahfuad100@gmail.com

3 Department of Disaster and Human Security Management, Bangladesh University of Professionals, Dhaka 1216, Bangladesh; mostafizur@bup.edu.bd

* Correspondence: musabber.chisty@du.ac.bd

\begin{abstract}
Increased levels of resilience will reduce the negative consequences of any disaster and develop the capacities of communities to mitigate future disasters. The main objective of this study was to measure the level of resilience of two different communities in two different study areas and compare the resilience levels in terms of a flood. The study used the Analysis of Resilience of Communities to Disasters (ARC-D) toolkit. The study was conducted in two different areas to compare the level of community resilience. Both quantitative and qualitative methods were used in the study. A structured questionnaire was developed by using the toolkit. Results of the study indicated that communities in study area 1 were more resilient than communities in study area 2 . Communities from study area 1 were more aware of their risk(s) and problem(s) and ensured proper strategies and actions to solve problems. On the other hand, communities in study area 2 were less aware of their risk(s). The strategies and actions implemented by the communities of study area 1 focused on the short-term problem(s), which reduced their level of resilience. Measuring resilience is very important in terms of developing disaster risk reduction (DRR) plans and incorporating DRR in the development process in lower-income countries and developing countries. As data scarcity is one of the major issues in developing countries, introducing a community resilience assessment mechanism can be a great help to reduce gaps in the planning and implementation process.
\end{abstract}

Keywords: community; resilience; measurement; risk; hazard; disaster

\section{Introduction}

Bangladesh is one of the most disaster-prone countries in the world. Bangladesh is situated in the south Asian sub-continent, and due to its unique geographical location, it is always the subject and victim of different kinds of disasters. According to World Risk Index 2019, Bangladesh stood in 10th position in the list of most risky countries around the world [1]. Disasters are almost an annual phenomenon here, that severely render the sustainable and progressive activities of the country. Between 1900 and 2016, ninety major flood events happened in Bangladesh, which cost 52,437 people their lives and almost 32 million people were directly affected [2]. Moreover, poverty, lack of resources, limited preparedness, lack of awareness, and gaps in response mechanisms make the scenario worse. In developing countries, lack of information and data, limited hazard assessment mechanisms, dynamic characteristics of vulnerabilities of the communities, and inadequate knowledge about disaster management also hamper the process of achieving resilience at the community level [3-6]. 
In the year 2020, floods in the northern part of Bangladesh caused significant destruction. The duration of the 2020 flood was longer than in previous years. Further, the water level was much higher than for regular monsoon floods [7]. Most of the districts in the northern part faced the consequences of the 2020 flood. The government and nongovernment organizations (NGOs) initiated different projects and programs to support the innocent victims of the flood. Still, they are struggling to adjust to the unfavorable situation as people are not rehabilitated properly following a systematic plan of resilience. After a disaster, recovery activities should focus more on increasing the community's resilience and all other support. The Sendai Framework for Disaster Risk Reduction (SFDRR) 2015-2030 is mainly introduced to make communities more pro-active and initiate action long before the strike of a disaster. All the four priorities of SFDRR are focused to reduce loss of lives, properties, and environment and to make communities resilient.

In English, the word 'resilience' is derived from the Latin words resilire and salire, which stand for leap back, recoil, and spring again. In common words, resilience is said to be the responsiveness of anything in a reflective manner [8]. Resilience can be defined from different disciplines, and there are complexities in developing consensus regarding the definition [8]. In disaster studies, resilience is the ability of any organization to rebound or spring back to normal operations after an event has occurred [8]. Mainly, resilience is seen as a condition or trait or process or outcome that can bend but not break. The system which is capable of bouncing back even grows in the face of an adverse experience [9]. According to $[10,11]$, resilience is related to the capacity of social units to reduce the effects of disasters and continue recovery activities after a disaster to reduce the disruption of social engagements. Furthermore, resilience is known as the ability of individuals to continue working in a given adverse condition [11,12]. Resilience is the level of capacity and resources of any community to organize itself before and during any hazardous event [13]. Resilience is known as the strategy or strength of someone or any society to adapt to face any traumatic situation and continue normal activities. Disaster resilience is related to the disturbance occurring from natural and human phenomenon and community coping capacity. Resilience has been seen as the combination of three criteria: capacity of a system to remain in the same domain but face changes in the system, capacity of a system to reorganize by itself, and capacity of a system to learn and cope with conditions [14]. The basic idea of community resilience is to bounce back to the previous position after any negative life events [15]. Community resilience has been identified in various ways by different researchers. According to [16], community resilience is a condition where the community will bounce forward to address the previous weaknesses and to take measures. It is also coined by [16] that community resilience is a transformational process rather than addressing the strengths of the community. The United Nations Environment Programme (UNEP) took another step to merge resilience with Disaster Risk Reduction (DRR). According to UNEP, through DRR, environments and eco-systems should revitalized to make communities and countries resilient [17]. In the study by [18], community resilience is seen from a public health perspective. As individual resilience is the adaptation strategy after facing an adverse event, community resilience is the ability of the community to sustain in adverse conditions and recover from negative events [18]. It has been identified by [19] that community resilience is not only related to social and natural context within which community lies but also related to the political and economic circumstances.

Community capacity is seen as an ability that will enhance the community's coping capacity after a disaster to manage future disasters [19]. In the work of [20], two major components are identified to define community disaster resilience: emergency adjustment and long-term adaptation capacity. According to [20], community disaster resilience is related to increasing disaster recovery capacity, introducing adjustment to an emergency, and ensuring long-term adaptation after a disaster, eventually reducing community vulnerability. It is also coined here that community disaster resilience is related to the community's social, political, economic, and environmental circumstances [20]. Community resilience is an ongoing process to develop community capacity to prevent or mitigate any stressful incident 
and ensure response, recovery, and restoration after an incident [21]. In [22], resilience is indicated as the capacity or ability of communities, cities, or groups to endure hazardous events and recover from such events. Thus, community resilience is the ability of the community to continue functioning during and after a disaster [22]. A study of community disaster resilience [23] defined community disaster resilience as "the capacity or the ability of a community to anticipate, prepare for, respond to, and recover quickly from impacts of disaster". Here, community disaster resilience is related to recovering from hazardous conditions and learning processes to cope with current and future hazards [23]. Community resilience depends on different social values, capacities, social capital, knowledge, expertise, skills, physical assets, relation, economic conditions, and political conditions, reducing vulnerabilities and increasing adaptation capacities [24].

From all these definitions and concepts, it is very clear that community disaster resilience depends on current capacities to endure a hazardous event and develop abilities to adapt to future events without disrupting regular functioning. In this case, it is important to assess the different current social, economic, political, and environmental capacities of the community so that initiatives can be designed to increase the level of resilience. Both short-term responses and long-term efforts should be included. The main objective of this study was to measure the level of resilience of two different communities in two different study areas by using the Analysis of Resilience of Communities to Disasters (ARC-D) toolkit and compare their level of resilience in terms of the flood. The research questions were: to what extent the communities are resilient, and what level of differences are there between the two communities in terms of resilience? Studies explored that making a community resilient is a complex process and it is not easy to define a community that is resilient for all disasters [25]. Thus, assessing the level of resilience of communities for an individual disaster can be effective. This study explicitly focused on floods to assess the resilience level of two different communities. The study used the ARC-D toolkit to showcase the interconnectedness of different components which enable a community to become resilient [26].

\section{ARC-D Toolkit}

There are different resilience assessment tools that are used to assess the level of resilience from different perspectives. Assessing community resilience is a complex activity. There is no standard tool to measure community resilience. Each tool measures and assesses community resilience with different objectives. It is important to specify why we need to measure community resilience and how we will utilize the results. Tools, such as the Community Disaster Resilience Index (CDRI) [27], Community Disaster Resilience Framework for Iran [28], Community Resilience Score Card [24], Community Resilience framework [29], and Communities Resilience Index [30], are used to measure and analyze community disaster resilience. In this study, we used the Analysis of Resilience of Communities to Disasters (ARC-D) toolkit developed by GOAL [31]. The ARC-D toolkit was developed to measure community resilience under a 10-year project by GOAL [31]. This tool was used in 11 different countries to ensure its credibility, validity, reliability, and applicability. A long research process and testing ensured the proper development of the ARC-D toolkit. There are 30 specific indicators in the ARC-D toolkit to measure community resilience (Table 1). This toolkit is initially derived from the Characteristics of Disaster Resilient Communities guidelines developed by [32]. The main reason for using the ARC-D toolkit in this study was to measure community resilience from a comprehensive perspective. The ARC-D toolkit was designed to assess the multi-dimensional level of community resilience and explore the areas for further development. The ARC-D toolkit not only measures community resilience but also refers to possible actions for the future. 
Table 1. ARC-D toolkit resilience components, questions, and measurement scores [31].

\begin{tabular}{|c|c|c|c|}
\hline S1. No. & Components & Questions & SFDRR Priority Areas \\
\hline 1 & $\begin{array}{l}\text { Participatory risk } \\
\text { assessment }\end{array}$ & $\begin{array}{c}\text { Has the community carried out a participatory risk assessment (hazard } \\
\text { analysis, vulnerability and capacity analysis (VCA), impact analysis), shared } \\
\text { the findings, and have human resources capable for conducting and updating } \\
\text { this assessment? }[31,33]\end{array}$ & \multirow{4}{*}{$\begin{array}{l}\text { Priority } 1: \\
\text { Understanding disaster risk }\end{array}$} \\
\hline 2 & $\begin{array}{l}\text { Scientific risk } \\
\text { assessment }\end{array}$ & $\begin{array}{l}\text { Does the community combine local knowledge and perceptions of risk with } \\
\text { scientific knowledge, data, and assessment methods? }[31,33]\end{array}$ & \\
\hline 3 & $\begin{array}{l}\text { Dissemination of } \\
\text { Disaster Risk } \\
\text { Reduction (DRR) } \\
\text { information }\end{array}$ & $\begin{array}{c}\text { Have community members been exposed to/have participated in DRR } \\
\text { specific awareness events (campaigns, discussions, and training) and have } \\
\text { improved awareness and practices as a result? }[31,33]\end{array}$ & \\
\hline 4 & $\begin{array}{l}\text { Education of children } \\
\text { on DRR }\end{array}$ & $\begin{array}{l}\text { Are DRR and recovery knowledge and capacities being passed on to children } \\
\text { formally through local schools and informally via oral tradition from one } \\
\text { generation to the next? }[31,33]\end{array}$ & \\
\hline 5 & $\begin{array}{l}\text { DRR in development } \\
\text { planning }\end{array}$ & $\begin{array}{c}\text { Does the community see DRR as an integral part of plans and actions to } \\
\text { achieve wider community goals (e.g., poverty alleviation, } \\
\text { quality of life)? }[31,33]\end{array}$ & \multirow{7}{*}{$\begin{array}{l}\text { Priority 2: } \\
\text { Strengthening disaster risk } \\
\text { governance to manage } \\
\text { disaster risk }\end{array}$} \\
\hline 6 & $\begin{array}{l}\text { DRR in land use } \\
\text { planning }\end{array}$ & $\begin{array}{c}\text { Does community decision-making regarding land use and management take } \\
\text { disaster risk into account? }[31,33]\end{array}$ & \\
\hline 7 & $\begin{array}{l}\text { Community } \\
\text { decision-making }\end{array}$ & Is the community leadership committed, effective, and accountable? $[31,33]$ & \\
\hline 8 & $\begin{array}{l}\text { Inclusion of } \\
\text { vulnerable groups }\end{array}$ & $\begin{array}{l}\text { Are the vulnerable groups in the community included and represented in } \\
\text { community decision-making and management of DRR and recovery? }[31,33]\end{array}$ & \\
\hline 9 & $\begin{array}{l}\text { Participation of } \\
\text { women }\end{array}$ & $\begin{array}{c}\text { Do women participate in community decision-making and management of } \\
\text { DRR and recovery? }[31,33]\end{array}$ & \\
\hline 10 & $\begin{array}{l}\text { Rights awareness and } \\
\text { advocacy }\end{array}$ & $\begin{array}{l}\text { Is the community aware of its rights, relevant legal mechanisms, and } \\
\text { responsible actors for their fulfillment, and does it advocate for these? [31,33] }\end{array}$ & \\
\hline 11 & $\begin{array}{l}\text { Partnerships for DRR } \\
\text { and recovery }\end{array}$ & $\begin{array}{l}\text { Are there clear, agreed, and stable partnerships between the community and } \\
\text { other actors (local authorities, NGOs, businesses, etc.) that provide resources } \\
\text { for DRR and recovery? [31,33] }\end{array}$ & \\
\hline 12 & $\begin{array}{l}\text { Sustainable } \\
\text { environmental } \\
\text { management }\end{array}$ & $\begin{array}{c}\text { Does the community adopt sustainable environmental management practices } \\
\text { that reduce disaster risk and new risks related to the effects of } \\
\text { climate change? }[31,33]\end{array}$ & \multirow{14}{*}{$\begin{array}{l}\text { Priority 3: } \\
\text { Investing in disaster risk } \\
\text { reduction for resilience }\end{array}$} \\
\hline 13 & $\begin{array}{l}\text { Water security and } \\
\text { management }\end{array}$ & $\begin{array}{l}\text { Does the community have access to sufficient quantity and quality of water for } \\
\text { domestic needs during disasters? }[31,33]\end{array}$ & \\
\hline 14 & $\begin{array}{l}\text { Health access and } \\
\text { awareness }\end{array}$ & $\begin{array}{l}\text { Do community members maintain good health in normal times through } \\
\text { appropriate awareness and practices (adequate nutrition, hygiene, and health } \\
\text { care access)? }[31,33]\end{array}$ & \\
\hline 15 & $\begin{array}{l}\text { Secure and sufficient } \\
\text { food supply }\end{array}$ & $\begin{array}{c}\text { Does the community have a secure and sufficient food supply during } \\
\text { disasters? }[31,33]\end{array}$ & \\
\hline 16 & $\begin{array}{l}\text { Hazard-resistant } \\
\text { livelihood practices }\end{array}$ & $\begin{array}{c}\text { Does the community employ hazard-resistant livelihood practices for food } \\
\text { and income security? }[31,33]\end{array}$ & \\
\hline 17 & Access to market & $\begin{array}{l}\text { Are the local market links for products, labor, and services protected against } \\
\text { shocks? }[31,33]\end{array}$ & \\
\hline 18 & $\begin{array}{l}\text { Access to } \\
\text { financial services }\end{array}$ & $\begin{array}{l}\text { Are there affordable and flexible financial services (savings and credit } \\
\text { schemes, microfinance), whether formal or informal? }[31,33]\end{array}$ & \\
\hline 19 & $\begin{array}{l}\text { Income and asset } \\
\text { protection }\end{array}$ & $\begin{array}{c}\text { Are household asset bases (income, savings, and convertible property) } \\
\text { sufficiently large and diverse, and protected to ensure reduced vulnerability to } \\
\text { disaster? }[31,33]\end{array}$ & \\
\hline 20 & Social protection & $\begin{array}{l}\text { Does the community have access to informal and formal social protection } \\
\text { schemes that support disaster risk reduction and recovery? }[31,33]\end{array}$ & \\
\hline 21 & $\begin{array}{l}\text { Social cohesion and } \\
\text { conflict prevention }\end{array}$ & $\begin{array}{l}\text { Is there a sense of peace, security, and effective conflict prevention and } \\
\text { mitigation mechanisms, both within the community and with other } \\
\text { communities? [31,33] }\end{array}$ & \\
\hline 23 & Critical infrastructure & $\begin{array}{c}\text { Are the community's critical infrastructure and basic services resilient to } \\
\text { disaster (e.g., located in low-risk areas, using hazard-resistant construction } \\
\text { methods, and structural mitigation measures)? [31,33] } \\
\text { Is the community's housing resilient to disaster (e.g., located in low-risk areas, } \\
\text { using hazard-resistant construction methods, and structural mitigation } \\
\text { measures)? [31,33] }\end{array}$ & \\
\hline 24 & $\begin{array}{l}\text { Contingency and } \\
\text { recovery planning }\end{array}$ & $\begin{array}{c}\text { Does the community use communally developed contingency and recovery } \\
\text { plans that are widely understood and include measures to protect vulnerable } \\
\text { groups? }[31,33]\end{array}$ & \\
\hline 25 & $\begin{array}{l}\text { Early warning system } \\
\text { Capacity in }\end{array}$ & Is there an operational early warning system in the community? $[31,33]$ & \\
\hline 26 & $\begin{array}{l}\text { preparedness, } \\
\text { response, and early } \\
\text { recovery }\end{array}$ & $\begin{array}{l}\text { Does the community have a trained and operating organization in disaster } \\
\text { preparedness, response, and early recovery? }[31,33]\end{array}$ & \\
\hline
\end{tabular}


Table 1. Cont.

\begin{tabular}{|c|c|c|c|}
\hline S1. No. & Components & Questions & SFDRR Priority Areas \\
\hline 27 & $\begin{array}{l}\text { Health services in } \\
\text { emergencies }\end{array}$ & $\begin{array}{c}\text { Does the community have access to health care facilities and health workers } \\
\text { equipped and trained to respond to physical and mental health consequences } \\
\text { of disasters, and supported by access to emergency health services, } \\
\text { medicines, etc.? }[31,33]\end{array}$ & \multirow{4}{*}{$\begin{array}{c}\text { Priority 4: } \\
\text { Enhancing disaster } \\
\text { preparedness for effective } \\
\text { response, and to "Build } \\
\text { Back Better" in recovery, } \\
\text { rehabilitation, and } \\
\text { reconstruction }\end{array}$} \\
\hline 28 & $\begin{array}{c}\text { Education services in } \\
\text { emergencies }\end{array}$ & \multirow{2}{*}{$\begin{array}{c}\text { Do education services have the capacity to continue operating } \\
\text { in emergencies? }[31,33] \\
\text { Are emergency shelters (purpose-built or modified) accessible to the } \\
\text { community and have adequate facilities to meet basic needs for all of the } \\
\text { affected population? }[31,33]\end{array}$} & \\
\hline 29 & $\begin{array}{l}\text { Emergency } \\
\text { infrastructure }\end{array}$ & & \\
\hline 30 & $\begin{array}{l}\text { Leadership and } \\
\text { volunteerism in } \\
\text { response and } \\
\text { recovery }\end{array}$ & $\begin{array}{l}\text { Does the community play a leading role in coordinating preparedness, } \\
\text { response, and recovery, reaching all affected people-including the most } \\
\text { vulnerable-through organized and trained volunteers? [31,33] }\end{array}$ & \\
\hline \multicolumn{4}{|c|}{ Measurement Score } \\
\hline Score & 1 & 3 & 5 \\
\hline Description & Minimum resilience & Approaching resilience & Resilience \\
\hline
\end{tabular}

\section{Data and Method}

\subsection{Research Approach}

The study used a mixed-method approach for collecting and analyzing data. Both qualitative and quantitative methods were used to conduct the study. The quantitative method was focused on the ARC-D tool to measure community resilience. Previous studies showed that this toolkit can be successfully used to measure community resilience in a collective approach [31,33-36]. On the other hand, the qualitative method focused on collecting data on communities' perspectives, beliefs, and practices related to resilience. The quantitative method helps to use different measurements to summarize and quantify results [37]. Through the qualitative method, experiences and practices are recorded to gain a descriptive view related research objective [37]. The study mainly followed the triangulation of methods that ensure the use of more than one method in a study to achieve a more reliable and valid result [37]. Previous community resilience assessment models divided scales in physical, environmental, economic, natural, and social resilience to gain a more in-depth view. However, this study did not follow the process. This can be indicated as a methodological limitation of this study.

\subsection{Study Area}

Due to the geographical context and physical distribution of rivers, Bangladesh faces flooding regularly every year. The main river systems, which are known as the Ganges, Brahmaputra, and Meghna river systems, bring a huge amount of water from upstream and cause devastating floods in this deltaic area [38]. Rivers in Bangladesh are mainly in the old stage and deposit massive amounts of sediment every year. Due to this reason drainage capacity of the river system is reducing every year [38]. When a massive amount of water passes through the country, it overflows nearby areas and creates devastating floods. This study had chosen two different areas that faced the major impact of the 2020 flood: Sirajganj and Bogura. According to the Need Assessment Working Group 2020 report, approximately 338,455 people were affected by the flood in Sirajganj. On the other hand, according to the same report total of 127,875 people were affected by the flood in Bogura [7]. Throughout the study, areas are referred to as study area $1=$ Sirajganj, and study area $2=$ Bogura.

\subsection{Sample Size and Sampling}

There were two study areas (Sirajganj and Bogura). Solvin's 1960 tool was used to select the sample size $[39,40]$. The formula and sample size are given below (Equation (1)):

$$
n=N /\left(1+N \times e^{2}\right)
$$


where $n=$ sample size, $N=$ total population affected by 2020 flood (Sirajganj $=338,455$, Bogura $=127,875)[7], e=$ margin of error $(5 \%)$ :

$$
\begin{gathered}
n=466330 /\left(1+466330 \times(5 \%)^{2}\right) \\
n=399.66
\end{gathered}
$$

A total of 435 respondents were surveyed during the study. After adjusting the missing responses with a 95 percent response rate, 413 responses were transferred for further assessment. After completing the coding and transcription of the data, finally, 410 responses were valid for final analysis. The samples were equally distributed in two study areas (Sirajganj $=205$, Bogura $=205$ ).

The study used the snowball sampling technique to select the samples in the study area. Snowball sampling is one of the major non-probability sampling techniques [37,41]. Under the snowball technique, primarily, the samples were selected randomly. After collecting data from a few samples, the respondents were asked to indicate from whom the study should collect the next responses. In this way the respondents who already participated in the study helped to select new samples. A network of samples was developed through this technique. Non-probability sampling techniques help to reach the convenient samples as much as possible [37,42]. The criteria to become a sample in the study were: the respondent must be 15 years old or above, be a permanent member of the study communities, and have faced the impacts of the 2020 flood.

\subsection{Data Collection Tool}

\subsubsection{Quantitative Method}

As part of the quantitative approach, a survey tool was used to collect the data. The ARC-D toolkit was followed to develop a structured questionnaire to collect data from the communities (Table 1). The questionnaire was administered by trained data enumerators who translated each question for the respondents and collected the responses. There is a total of 30 components in the ARC-D toolkit. There are specific questions for specific components with a special measurement scale [31]. Responses of questions were collected using a 5-level Likert scale representing $1=$ minimum resilience and $5=$ full resilience (Table 1). The components of the toolkit are also aligned with the priorities of the Sendai Framework for Disaster Risk Reduction (SFDRR) 2015-2030.

\subsubsection{Qualitative Method}

The study also used an observation tool as part of the qualitative method. The observation tool helps to gain a broader picture of any field and collect perspective-based information [37]. The main reason behind using a qualitative tool is to gather the information that will support or deny the quantitative findings. Only number-based results are not enough to develop a comprehensive picture of the study communities.

\subsection{Data Analysis}

Quantitative data were coded and analyzed using IBM SPSS version 25 [43]. The descriptive statistical analysis helped to assess the resilience level. The whole quantitative analysis followed the process from the ARC-D toolkit. Responses of the samples were analyzed, and the mean values were gathered for each component. With the total mean value of each community, the level of resilience was defined. Table 2 shows the scale for assigning community resilience levels according to the ARC-D score [31]. The qualitative data were analyzed based on commonality and differences in the responses. All the common responses were accumulated and discussed with quantitative findings. 
Table 2. Community resilience levels [31].

\begin{tabular}{|c|c|c|}
\hline Resilience Level & Score & Description \\
\hline Very low resilience & $30-45$ & Very limited awareness and knowledge of the problem(s). No action taken $[31,33]$ \\
\hline Low resilience & $46-75$ & $\begin{array}{l}\text { A certain awareness of the problem(s), willingness to act, some actions taken, but actions are } \\
\text { fragmented, and solutions are only short term }[31,33]\end{array}$ \\
\hline Medium resilience & 76-105 & $\begin{array}{c}\text { Awareness of the problems and long-term actions taken, but not related to a long-term strategy } \\
\text { and/or addressing all aspects of the problem(s) }[31,33]\end{array}$ \\
\hline Close to resilience & $106-135$ & $\begin{array}{l}\text { Long-term actions, in accordance with a predefined strategy, addressing the main aspects of the } \\
\text { problem(s), but are inhibited by persistent shortcomings in their implementation }[31,33]\end{array}$ \\
\hline Resilience & $136-150$ & $\begin{array}{l}\text { Long-term actions are undertaken in accordance with a pre-defined strategy assessing all aspects } \\
\text { of the problem(s); they are sustainable and supported by the community }[31,33]\end{array}$ \\
\hline
\end{tabular}

\subsection{Ethical Considerations}

The project proposal and tools were ethically reviewed and approved by the institutional ethical review committee of the Institute of Disaster Management and Vulnerability Studies, University of Dhaka. The committee included both internal and external members. All the respondents participated in the study voluntarily. Prior consent was collected before collecting the data. During the whole study, the research team followed a strong ethical guideline in every stage.

\section{Results}

\subsection{Socio-Demographic Information}

Demographic information showed that 55.6 percent of the respondents were male, and 44.4 percent were female. As getting access to women of the household was difficult in the study areas, the number of female respondents is comparatively low. The majority of the respondents were from the 26-35 years age group. Most of the respondents were married and did not have any formal education. The income and expense levels among the respondents were very low. A significant number of respondents depended on peer group-based loans to maintain their families. A low level of income represents a higher level of economic vulnerability (Table 3).

Table 3. Socio-demographic information of the respondents.

\begin{tabular}{|c|c|c|c|c|c|}
\hline \multirow{2}{*}{ S1. No. } & \multirow{2}{*}{ Characteristics } & \multicolumn{2}{|c|}{ Percent } & \multirow{2}{*}{$p$-Value } & \multirow{2}{*}{ Df } \\
\hline & & Study Area 1 & Study Area 2 & & \\
\hline \multirow{4}{*}{1} & Sex & & & \multirow{4}{*}{0.426} & \multirow{4}{*}{1} \\
\hline & Male & 28.8 & 26.8 & & \\
\hline & Female & 21.2 & 23.2 & & \\
\hline & Age & & & & \\
\hline \multirow{5}{*}{2} & $<18$ & 2.2 & 1.7 & \multirow{5}{*}{$0.002^{* *}$} & \multirow{5}{*}{36} \\
\hline & $18-25$ & 12.7 & 11.9 & & \\
\hline & $26-35$ & 14.7 & 14.7 & & \\
\hline & $36-45$ & 10.1 & 12.2 & & \\
\hline & $>45$ & 10.3 & 9.5 & & \\
\hline \multirow{3}{*}{3} & Marital status & & & & \\
\hline & Single & 5.4 & 2.7 & \multirow{3}{*}{0.087} & \multirow{3}{*}{2} \\
\hline & Married & 44.6 & 47.3 & & \\
\hline \multirow{5}{*}{4} & Educational status & & & & \\
\hline & No formal education & 23.9 & 25.4 & \multirow{4}{*}{$0.024 *$} & \multirow{4}{*}{7} \\
\hline & Primary level & 11.7 & 16.3 & & \\
\hline & Secondary level & 10.7 & 7.4 & & \\
\hline & Higher secondary level and above & 3.7 & 0.9 & & \\
\hline
\end{tabular}


Table 3. Cont.

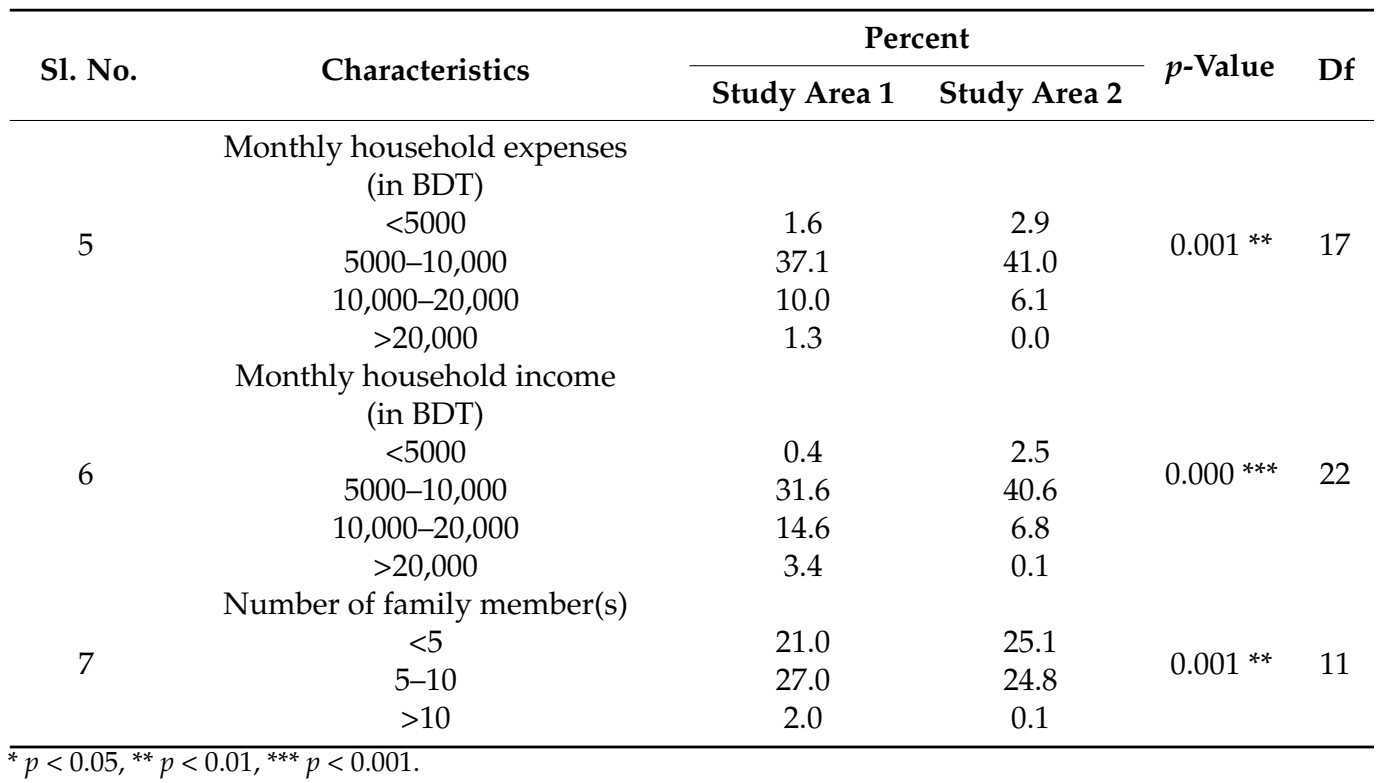

\subsection{Community Resilience Level}

The following section discusses the results of community resilience measurement activity. In the methodology section, the scoring system and process of collecting data are already discussed. The results in Table 4 are presented to clearly show the comparison of the level of community resilience between the two study areas.

Communities in study area 1 saw disasters as an integral part of their development process. They tried to include disaster-related issues in their development activities. As a result, they have scored a medium level of resilience. On the other hand, communities in study area 2 mostly did not have any idea about how to include disasters in development planning (Table 4). Some of the community members thought about disasters during their livelihood planning. For this reason, they have scored a lower level of resilience. Communities in both study areas were not greatly aware of DRR in land use planning. Due to this, both of the study areas showed low resilience levels in DRR related land use. Community leaders in study area 1 were very proactive related to DRR related activities. The majority of the respondents from study area 1 shared that local leaders work effectively in the pre, during, and post phases of a flood. However, community leaders and political members of study area 2 were not very active in the phases of a flood. Most of the respondents in study area 2 regretted that they did not see that many interventions from community leaders during the recent flood. Both study areas still lag behind in terms of ensuring inclusiveness in the DRR process. Vulnerable groups, especially women, did not receive many opportunities to share their voices in the decisionmaking platforms. Qualitative data disclosed that limited education and a lower level of income make people more vulnerable to disasters. These vulnerable were socially deprived by other community members. Following this, in both study areas, people were not greatly aware of their rights and legal mechanisms related to DRR. Though communities in study area 1 scored better on the resilience measurement scale, there were still areas for development. Due to the availability of different NGOs in study area 1, the partnershiprelated resilience was comparatively better in study area 1 . However, the communities in study area 2 lagged in partnership-related resources, which hindered their level of resilience. Altogether, study area 1 was in a better position in the governance-related resilience components. Strengthening disaster risk governance is one of the priorities of SFDRR (2015-2030). Ensuring participation of community members in decision-making platforms, building the capacity of local governments, developing a partnership with different organizations, mobilizing resources to vulnerable areas, including at-risk groups in 
the planning process, and prioritizing the needs of communities can support strengthening the disaster risk governance.

Table 4. Community resilience level scores [31,33].

\begin{tabular}{|c|c|c|c|c|c|c|}
\hline \multirow{2}{*}{ S1. No. } & \multirow{2}{*}{ Component } & \multicolumn{2}{|c|}{$\bar{x}$} & \multicolumn{2}{|c|}{$\sigma$} & \multirow{2}{*}{$p$-Value } \\
\hline & & Study Area 1 & Study Area 2 & Study Area 1 & Study Area 2 & \\
\hline 1 & Participatory risk assessment & 3.67 & 1.78 & 1.032 & 0.538 & \multirow{31}{*}{$0.000^{* * *}$} \\
\hline 2 & Scientific risk assessment & 3.50 & 1.86 & 1.008 & 0.570 & \\
\hline 3 & Dissemination of DRR information & 3.24 & 1.77 & 1.241 & 0.509 & \\
\hline 4 & Education of children on DRR & 3.18 & 1.88 & 1.241 & 0.524 & \\
\hline 5 & DRR in development planning & 3.00 & 1.72 & 1.122 & 0.452 & \\
\hline 6 & DRR in land use planning & 2.59 & 1.92 & 0.833 & 0.713 & \\
\hline 7 & Community decision-making & 3.46 & 1.87 & 1.319 & 0.367 & \\
\hline 8 & Inclusion of vulnerable groups & 2.07 & 1.61 & 0.918 & 0.588 & \\
\hline 9 & Participation of women & 2.87 & 1.56 & 1.399 & 0.517 & \\
\hline 10 & Rights awareness and advocacy & 2.91 & 1.72 & 1.312 & 0.520 & \\
\hline 11 & Partnerships for DRR and recovery & 3.31 & 1.56 & 1.501 & 0.497 & \\
\hline 12 & Sustainable environmental management & 2.14 & 1.79 & 1.022 & 0.723 & \\
\hline 13 & Water security and management & 3.92 & 4.07 & 0.794 & 0.671 & \\
\hline 14 & Health access and awareness & 1.91 & 2.98 & 1.020 & 1.014 & \\
\hline 15 & Secure and sufficient food supply & 2.13 & 1.53 & 1.050 & 0.547 & \\
\hline 16 & Hazard-resistant livelihoods practices & 1.84 & 1.62 & 0.685 & 0.579 & \\
\hline 17 & Access to market & 1.61 & 1.30 & 0.659 & 0.458 & \\
\hline 18 & Access to financial services & 2.10 & 1.66 & 1.005 & 0.559 & \\
\hline 19 & Income and asset protection & 1.83 & 1.58 & 0.818 & 0.495 & \\
\hline 20 & Social protection & 2.27 & 1.65 & 1.143 & 0.487 & \\
\hline 21 & Social cohesion and conflict prevention & 3.50 & 3.66 & 0.958 & 0.891 & \\
\hline 22 & Critical infrastructure & 2.13 & 1.66 & 0.989 & 0.474 & \\
\hline 23 & Housing & 2.15 & 1.50 & 1.009 & 0.520 & \\
\hline 24 & Contingency and recovery planning & 2.42 & 1.60 & 0.869 & 0.490 & \\
\hline 25 & Early warning system & 3.41 & 1.60 & 1.475 & 0.566 & \\
\hline 26 & $\begin{array}{c}\text { Capacity in preparedness, response and } \\
\text { early recovery }\end{array}$ & 4.08 & 2.08 & 0.772 & 0.527 & \\
\hline 27 & Health services in emergencies & 1.84 & 1.76 & 1.078 & 0.481 & \\
\hline 28 & Education services in emergencies & 1.70 & 1.55 & 0.717 & 0.537 & \\
\hline 29 & Emergency infrastructure & 3.55 & 4.19 & 1.054 & 0.519 & \\
\hline \multirow[t]{2}{*}{30} & $\begin{array}{l}\text { Leadership and volunteerism in } \\
\text { response and recovery }\end{array}$ & 3.29 & 1.53 & \multirow[t]{2}{*}{1.425} & \multirow[t]{2}{*}{0.573} & \\
\hline & Total Score & 81.62 & 60.56 & & & \\
\hline
\end{tabular}

${ }^{* *} p<0.01,{ }^{* * *} p<0.001$.

In the participatory risk assessment component, study area 1 scored a medium level of resilience. On the other hand, study area 2 showed a low level of resilience. Following this, study area 1 also showed a medium level of resilience in terms of scientific risk assessment, whereas study area 2 lagged behind. In study area 1, respondents agreed that they had participated in DRR related different training and awareness-raising programs which ensured effective dissemination of DRR information. On the other hand, communities from study area 2 had very little opportunity to participate in DRR information dissemination programs. Furthermore, in study area 1, respondents shared that schools in their communities had formal structures to share DRR related knowledge with children. Whereas children from study area 2 rarely heard about DRR related information in their schools (Table 4). Qualitative data indicated that communities in study area 1 received risk assessment-related training from different non-governmental organizations (NGOs) which were working in their area for a long time. These NGOs organized different awareness-raising programs too. Observation-based data explored that in study area 2, there was almost no intervention related to DRR related knowledge sharing, which ultimately reduced the possibilities of the communities to understand the disaster in their area. If community members become 
aware of the risks, they will increase their level of preparedness. One of the first stages to become resilient is identifying the risks. The first priority of SFDRR is also understanding disaster risk. If the communities can assess their risks, they will be able to propose possible preparedness measures too.

Both of the study area communities were not very aware of sustainable environmental management activities (Table 4). However, communities in study area 1 had shown some practices related to environmental management, including specific places in the community for garbage deposition, planting trees near riverbanks to reduce erosion during and after a flood, using modern sanitation systems, and avoiding open defecation, etc. In such a scenario, communities in study area 2 did not have many activities related to sustainable environmental management. These data related to community practices were collected through the qualitative tool. In some components, study area 2 scored better than study area 1 . One of them was water security and management. Due to raising the tube wells, communities in study area 2 had access to safe drinking water during the recent flood. Communities in study area 1 were also working to raise their water sources and increase resilience. In components, such as health access and awareness, social cohesion, and conflict prevention, study area 2 showed a better level of resilience than study area 1 . Communities in study area 2 were relatively more aware of healthy practices and had better access to healthcare during normal periods than study area 1. Furthermore, communities in study area 2 were more cautious about preventing conflicts. Qualitative data indicated that the community feeling was higher among the respondents of study area 2. In study area 2, community members rush to support each other during a disaster with limited resources. On the other hand, study area 1 had areas to develop related to healthy practices and social cohesion. Other than these several components, study area 1 scored higher than study area 2, including secure and sufficient food supply, hazard-resistant livelihood practices, access to market, access to financial services, income and asset protection, social protection, critical infrastructure, and housing. Qualitative data showed that study area 1 received more resources from both internal (government) and external (NGOs) agencies related to these components, which supported them to score comparatively better than study area 2. Individually, however, study area 1 was lagging behind, and there were areas for improvement. Increasing investment for increasing disaster resilience should be a priority in both study areas. Disaster Risk Reduction (DRR) related investments can come from both governmental and non-governmental agencies. The priority of these investments should be increasing levels of resilience within communities.

Respondents of study area 1 shared that they received training related to contingency and recovery planning (Table 4). Most of the respondents in study area 1 took measures before the monsoon so that they could manage the flood, which was imminent to take place. On the other hand, respondents in study area 2 were not aware of contingency planning. Though they did practice individual preparedness, there was no sign of community-based contingency and recovery planning. In study area 1 , respondents had a community-based flood early warning system. An NGO helped them to install a water level measurement scale in the river near the study area. The NGO also provided training to communities about measuring water levels, monitoring and disseminating warnings, and ensuring proper response to the warnings. At the same time, there was no community-based warning system in study area 2. Respondents shared that they learned about the recent flood from radios and from SMS communication from their relatives who faced flooding before them. The absence of a community-based flood warning system increases vulnerability and reduces resilience. It was only in the emergency infrastructure component that study area 2 scored higher than study area 1 . There were a large number of flood shelter centers in study area 2 which increased their infrastructure-related resilience. The number of flood shelter centers in study area 1 was comparatively low. Other than this, in components such as capacity in preparedness, education in emergencies, and leadership and volunteerism in response recovery, respondents from study area 1 showed a higher level of resilience than study area 1. Qualitative data explored that external interventions from NGOs were 
the main reason for a higher level of community resilience. External interventions helped communities of study area 1 to become more prepared for responding to floods and for recovering effectively. Communities will be more resilient if the level of preparedness is increased for effective response and recovery.

There is a significant relationship between the components and the study areas $(p<0.001$, $p<0.01)$. The relationship indicates that the level of resilience differs in terms of study areas. Due to physical, economic, social, environmental, cultural, and institutional vulnerabilities, study areas achieved a different level of resilience in each component. The total resilience score of study area 1 was 81.62, and study area 2 was 60.56 (Table 4). According to the community resilience level score (Table 2), the total score of study area 1 represented a medium level of resilience. According to the description, the communities in study area 1 were aware of the problem(s) in their area, and they had taken some sort of long-term action related to the problem(s), but these actions and strategies did not cover all the aspects of the problem(s). Moreover, the strategies implemented to increase the level of resilience in study area 1 were not focused on the long-term perspectives. On the other hand, the total resilience score of the study area represented a low level of resilience. According to the description from Table 2, the communities in study area 1 were aware of the problem(s) to some extent, and there were some actions and strategies to manage those problems. However, these actions were only for short-term solutions to the problems. Results concluded that study area 1 was comparatively more resilient than study area 2 .

\section{Discussion}

The results already indicated the difference in community resilience between the two areas. The study should also reflect the community resilience from the Sendai Framework for Disaster Risk Reduction (SFDRR) 2015-2030 perspective. According to Table 1, the components are related to the four priorities of SFDRR. Figure 1 shows community resilience based on the priorities of SFDRR.

There were four components under priority 1 (Table 1). In understanding disaster risk, study area 1 scored 13.59, whereas study area 2 scored 7.29 (Figure 2). The main reason for the higher resilience level of study area 1 was external interventions. The communities of study area 1 developed partnerships with different NGOs, which increased their capacities to understand the risks. Communities received training and participated in awarenessraising programs organized by the NGOs, which helped them to strengthen their resilience. A completely different picture was seen in study area 2 . The communities in study area 2 rarely participated in any risk assessment-related activities. They were aware of the risks in their area by their own traditional knowledge. Moreover, a small number of interventions were seen in study area 2 to raise awareness of disasters such as floods. Disaster-related information was not disseminated at the community level. Formal educational institutions, such as schools, did not have any programs related to DRR. Thus, the level of understanding of disaster risk was low in study area 2. Understanding disasters and sharing information related to disasters are vital components to make communities resilient [44]. Participating in different decision-making platforms and assessment processes is important as these will help communities to understand the risk of disasters and work to reduce risk [28]. Human capital, such as education, knowledge about disasters, and information related to risk, help to implement risk reduction strategies and increase community disaster resilience [23]. This study summarizes that activities, such as training for community members related to DRR, organizing awareness-raising programs, incorporating DRR related knowledge in the formal education system, introducing participatory risk assessment, and including vulnerable groups in assessment, will help communities to understand disaster risks and increase the level of community resilience. 


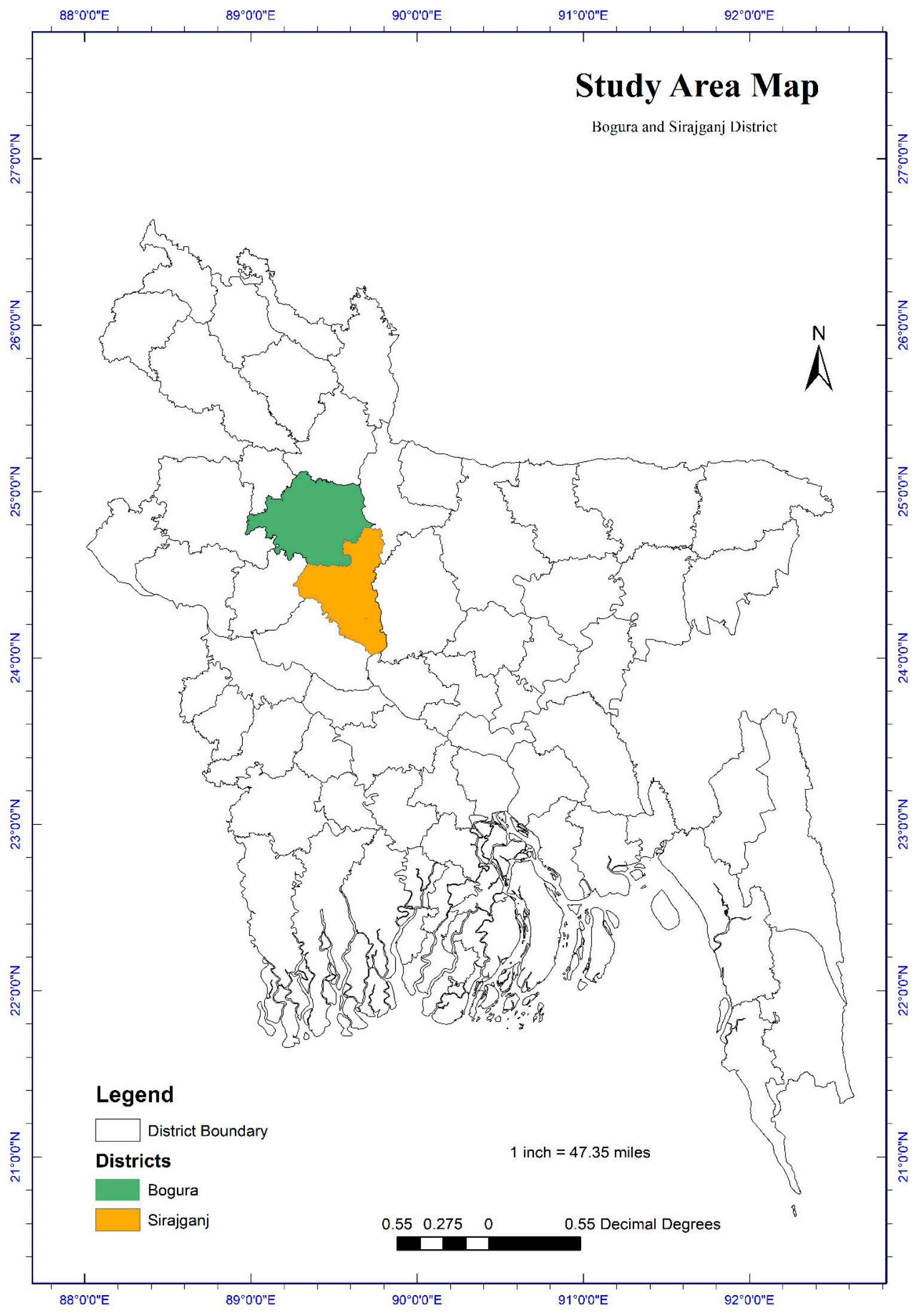

Figure 1. Study area map (source: developed by the study). 


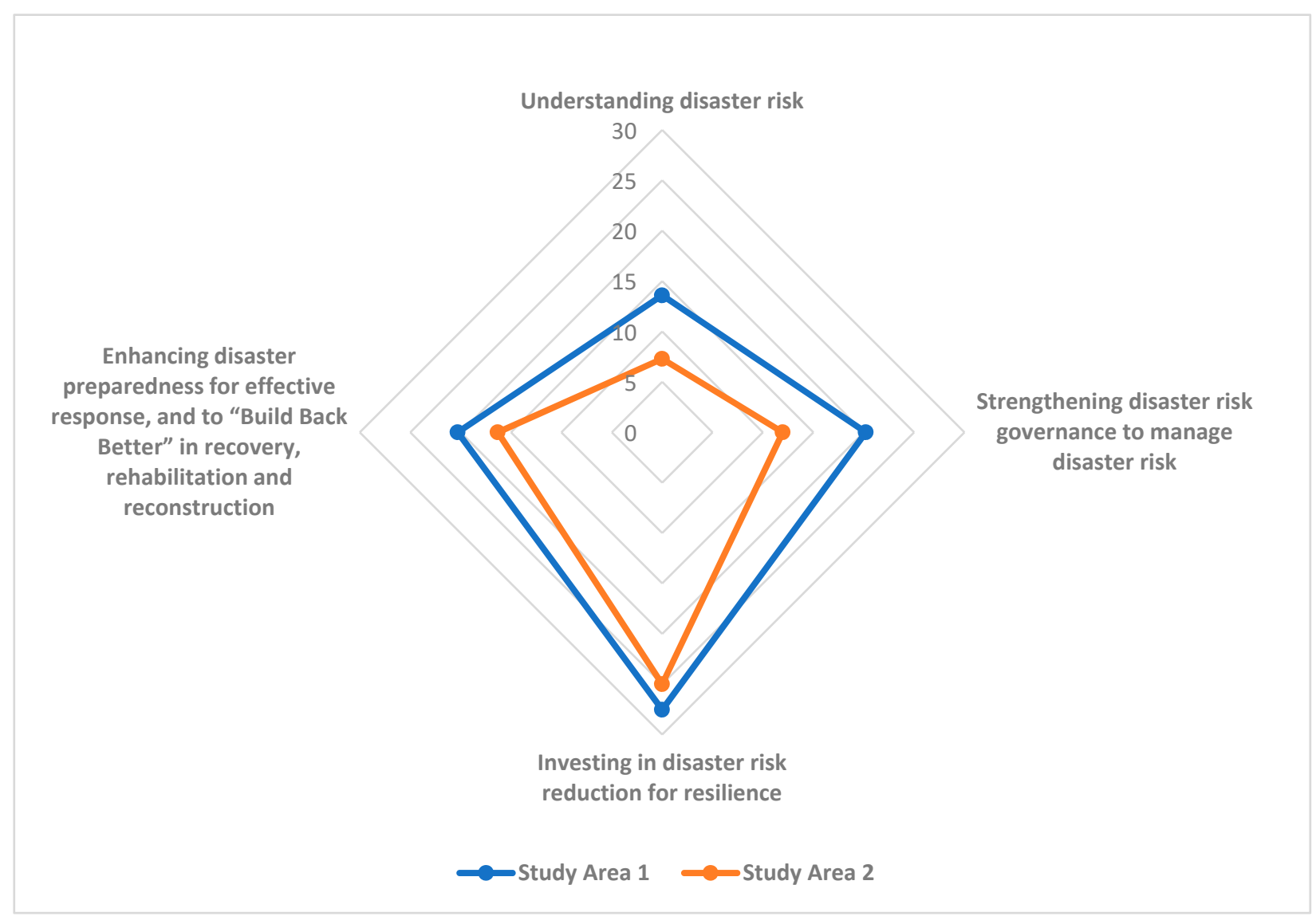

Figure 2. Community Resilience Level (Based on SFDRR Priorities).

Priority 2 had seven components (Table 1). Study area 1 also showed a higher level of resilience in terms of disaster risk governance. The score was 20.21 (Figure 2). Local government and community-based organizations (CBOs) tried to ensure the participation of community members in the decision-making process. Communities in study area 2 were more aware of their rights and responsibilities. Further, women and other vulnerable groups in study area 2 had the opportunity to be included in the DRR process. These reasons supported communities in study area 2 to achieve a higher level of resilience. On the other hand, study area 1 scored 11.96 in disaster risk governance points. The reasons behind the lower level of community resilience were limited access to decision-making platforms, lack of participation of women and other vulnerable groups in DRR activities, ineffective local government agencies, and a lower level of partnership with non-governmental agencies. Studies explored that availability of a strong local government, inclusion of vulnerable populations, equal socio-economic development, and enhancement of community capacities can increase community disaster resilience $[30,45,46]$. Furthermore, policies that are developed through prioritizing the needs of vulnerable groups can promote community resilience [45]. DRR related training programs for local government agencies can be one of the major interventions to strengthen disaster risk governance. If personnel-related local governments learn about interventions that can reduce disaster risk, they will ensure an inclusive DRR approach. Along with this, it is also important to increase the capacity of at-risk groups. Women, children, persons with disabilities, and elderly people, should be prioritized in DRR planning and programs. Reducing vulnerabilities through strong disaster risk governance will make communities resilient.

In the third priority, communities from both of the study areas scored very closely. The community resilience level of study area 1 was 27.53 , and study area 2 was 25.0 (Figure 2). Though both of the study areas scored very closely, the community resilience level was still low. There were 12 components in priority 3 (Table 1). A lower level of 
community resilience indicated that there were areas, such as health access during the normal period, access to financial services and markets, social protection, critical infrastructure, housing, and income and asset protection, that needed more interventions. Investing more to reduce disaster risk will also increase community resilience. Previous studies identified the importance of each component to make a community resilient. For instance, social capital and access to economical supports were seen as major variables to improve levels of community resilience $[47,48]$. Resources, such as social networks, communication infrastructure, transportation, livelihood and employment, economic development, and funding, etc., are seen as capitals which construct the framework to make communities resilient $[49,50]$. Furthermore, economic stability, equitable income, access to healthcare facilities, availability of critical infrastructure, and sense of community, etc., are also identified as major components to uphold a community as resilient [51-53]. For the study areas, local organizations, national agencies, governmental organizations, international development agencies, and private companies should invest more in these areas to make communities resilient. A developed healthcare system, shock-resistant critical infrastructures, strategies to protect income and assets, inclusive social protection programs, and accessible financial services can increase the level of community resilience. All of these interventions need a higher level of investment.

There were seven components in priority 4 (Table 1). Study area 1 scored 20.29, and study area 2 scored 16.31 in this priority area of SFDRR (Figure 2). Effective disaster preparedness and response depend on several factors, such as contingency planning, education in emergencies, access to health care during emergencies, crisis-related infrastructures such as flood shelter centers, and voluntary activities of different groups. Communities in study area 1 were well ahead in terms of disaster preparedness and recovery planning than communities in study area 1 . To enhance the level of preparedness for effective response, government and non-government agencies in study area 2 should come forward. Availability of a recovery plan and business continuity plan, increasing preparedness capacity of communities through training and awareness raising, including exercise and drills in the education system before disasters, improving resources to continue education during disasters and properly managing critical infrastructure such as emergency shelters, etc., will support the process of making communities resilient [54,55]. Involving communities in developing contingency planning can ensure effective response after a disaster and make communities resilient [56]. Furthermore, developing volunteer groups to support vulnerable populations during emergencies will amplify the level of community disaster resilience [57]. The idea of resilience is related to the idea of 'build back better'. Community resilience depends on the capacity of the community, which helps to absorb any shock and cope with the new condition. After any disaster, communities should focus on building their capacity to cope with similar disasters in the future. The idea of resilience is mainly related to response and recovery. If a community can effectively respond to any disaster and recover from the effects in the shortest period then that community will be identified as resilient. Moreover, recovery-related activities must make the community strong enough to absorb a similar level of shocks in the future.

\section{Conclusions}

The study used the ARC-D toolkit to measure community resilience in two different areas. In nature, the study followed a comparative analysis style. Both study areas had scopes to enhance their resilience. The results indicated that communities in study area 1 were more resilient than study area 2 . The ARC-D toolkit helped not only to measure community resilience but also to show the areas which needed immediate attention. Measuring community resilience is very important in developing DRR plans and incorporating DRR in the development process. If concerned authorities are not aware of the level of resilience of different communities, development plans will not be fruitful. A clearer picture of community resilience can be developed if the community receives the opportunity to share its perspectives related to DRR. Involving communities in every aspect of DRR will 
help to create ownership and ensure the sustainability of interventions. Using a tool that involves the community in measuring resilience should be prioritized. The ARC-D toolkit has the efficiency to support concerned authorities by measuring community resilience and providing inputs for future planning. As previous literature explained, successful use of this tool in different contexts, as in this study, will strengthen the appropriateness of this tool to be applicable in developing countries.

Author Contributions: Conceptualization, M.A.I. and M.A.C.; methodology, M.A.C.; software, M.A.C. and A.F.; validation, M.A.C., A.F., M.M.R. and S.E.A.D.; formal analysis, M.A.I., M.A.C., M.M. and F.J.B.; investigation, M.A.C., S.E.A.D., M.M.R., F.J.B. and N.A.K.; resources, M.A.I., M.A.C. and N.A.K.; data curation, M.A.C., A.F., M.M.R., S.E.A.D. and M.M.; writing-original draft preparation, M.A.C., M.M., F.J.B. and N.A.K.; writing—review and editing, M.A.I., M.A.C., M.M.R., S.E.A.D., F.J.B. and N.A.K.; visualization, M.A.C.; supervision, M.A.C.; project administration, M.A.C.; funding acquisition, M.A.I. All authors have read and agreed to the published version of the manuscript.

Funding: The study did not receive any funding.

Institutional Review Board Statement: The study was conducted according to the guidelines of the Declaration of Helsinki and approved by the Ethical Review Committee of the Institute of Disaster Management and Vulnerability Studies, University of Dhaka, Dhaka-1000, Bangladesh (date of Approval: 3 August 2020).

Informed Consent Statement: Informed consent was obtained from all subjects involved in the study.

Data Availability Statement: Data will be shared on a requirement basis.

Acknowledgments: The study acknowledges the support of the University of Dhaka. Furthermore, the study acknowledges the support of all the respondents of the study. Also, the study acknowledges the support of persons who were involved in data collection, data cleaning and digitization, data analysis, and proofreading activities.

Conflicts of Interest: The authors declare no conflict of interest.

\section{References}

1. Bündnis Entwicklung Hilft, Ruhr University Bochum-Institute for International Law of Peace and Armed Conflict (IFHV). World Risk Report 2019_Focus: Water Supply; Bündnis Entwicklung Hilft, Ruhr University Bochum—Institute for International Law of Peace and Armed Conflict: Berlin/Heidelberg, Germany, 2019; Available online: https:/ / reliefweb.int/sites/reliefweb. int/files / resources/WorldRiskReport-2019_Online_english.pdf (accessed on 2 June 2021).

2. Centre for Research on the Epidemiology of Disasters-CRED. EM-DAT: The Emergency Events Database-Université catholique de Louvain (UCL). Available online: www.emdat.be (accessed on 2 June 2021).

3. Pinos, J.; Quesada-Román, A. Flood Risk-Related Research Trends in Latin America and the Caribbean. Water 2021, 14, 10. [CrossRef]

4. García-Soriano, D.; Quesada-Román, A.; Zamorano-Orozco, J.J. Geomorphological hazards susceptibility in high-density urban areas: A case study of Mexico City. J. S. Am. Earth Sci. 2020, 102, 102667. [CrossRef]

5. Quesada-Román, A.; Ballesteros-Cánovas, J.A.; Granados-Bolaños, S.; Birkel, C.; Stoffel, M. Improving regional flood risk assessment using flood frequency and dendrogeomorphic analyses in mountain catchments impacted by tropical cyclones. Geomorphology 2021, 396, 108000. [CrossRef]

6. Quesada-Román, A.; Castro-Chacón, J.P.; Boraschi, S.F. Geomorphology, land use, and environmental impacts in a densely populated urban catchment of Costa Rica. J. S. Am. Earth Sci. 2021, 112, 103560. [CrossRef]

7. Needs Assessment Working Group (NAWG). Bangladesh: Monsoon Floods 2020 Coordinated Preliminary Impact and Needs Assessment; Needs Assessment Working Group: Dhaka, Bangladesh, 2020; Available online: https:/ / reliefweb.int/sites/reliefweb.int/files / resources/nawg_monsoon_flood_preliminary_impact_and_kin_20200725_final_draft.pdf (accessed on 2 June 2021).

8. Wattie, J.; Masys, A.J. Enabling Resilience: An Examination of High Reliability Organizations and Safety Culture through the Lens of Appreciative Inquiry. In Disaster Management: Enabling Resilience. Lecture Notes in Social Networks; Masys, A., Ed.; Springer: Cham, Switzerland, 2015; pp. 157-176. [CrossRef]

9. Southwick, S.M.; Bonanno, G.A.; Masten, A.; Panter-Brick, C.; Yehuda, R. Resilience definitions, theory, and challenges: Interdisciplinary perspectives. Eur. J. Psychotraumatol. 2014, 5, 25338. [CrossRef]

10. Bruneau, M.; Chang, S.E.; Eguchi, R.T.; Lee, G.C.; O’Rourke, T.D.; Reinhorn, A.M.; Shinozuka, M.; Tierney, K.; Wallace, W.A.; von Winterfeldt, D. A Framework to Quantitatively Assess and Enhance the Seismic Resilience of Communities. Earthq. Spectra 2003, 19, 733-752. [CrossRef] 
11. Bhamra, R.S.; Dani, S.; Burnard, K.J. Resilience: The concept, a literature review and future directions. Int. J. Prod. Res. 2011, 49, 5375-5393. [CrossRef]

12. Paton, D.; Smith, L.; Violanti, J. Disaster response: Risk, vulnerability and resilience. Disaster Prev. Manag. Int. J. 2000, 9, 173-180. [CrossRef]

13. Etkin, D. Disaster Theory: An Interdisciplinary Approach to Concepts and Causes, 1st ed.; Butterworth-Heinemann Elsevier Ltd: Oxford, UK, 2014; p. 368.

14. Shaw, R.; Sharma, A. (Eds.) Climate and Disaster Resilience in Cities; Community, Environment and Disaster Risk Management, Volume 6; Emerald Group Publishing Limited: Bingley, UK, 2011. [CrossRef]

15. Ronan, K.R.; Johnston, D.M. Promoting Community Resilience in Disasters: The Role for Schools, Youth, and Families; Springer Science + Business Media, Inc.: New York, NY, USA, 2005; p. 221.

16. Ride, A.; Bretherton, D. Conclusion: Community Resilience in Natural Disasters. In Community Resilience in Natural Disasters, Palgrave Macmillan: New York, NY, USA, 2011; pp. 169-193.

17. Nehren, U.; Sudmeier-Rieux, K.; Sandholz, S.; Estrella, M.; Lomarda, M.; Guillén, T. The Ecosystem-Based Disaster Risk Reduction Case Study and Exercise Source Book, 1st ed.; Partnership for Environment and Disaster Risk Reduction and Center for Natural Resources and Development: Geneva, Switzerland; Cologne, Germany, 2014.

18. Plough, A.; Fielding, J.E.; Chandra, A.; Williams, M.; Eisenman, D.; Wells, K.B.; Law, G.Y.; Fogleman, S.; Magana, A. Building Community Disaster Resilience: Perspectives From a Large Urban County Department of Public Health. Am. J. Public Health 2013, 103, 1190-1197. [CrossRef]

19. Joerin, J.; Shaw, R.; Takeuchi, Y.; Krishnamurthy, R. Assessing community resilience to climate-related disasters in Chennai, India. Int. J. Disaster Risk Reduct. 2012, 1, 44-54. [CrossRef]

20. Chen, L.-C.; Wang, Y.-W. Building community capacity for disaster resilience in Taiwan. J. Disaster Res. 2010, 5, 138-146. [CrossRef]

21. Chandra, A.; Acosta, J.; Stern, S.; Uscher-Pines, L.; Williams, M.V.; Yeung, D.; Garnett, J.; Meredith, L.S. Definition and Application of Community Resilience. In Building Community Resilience to Disasters; RAND Corporation: Santa Monica, CA, USA, 2011; pp. 7-10.

22. National Research Council. Building Community Disaster Resilience through Private-Public Collaboration; The National Academies Press: Washington, DC, USA, 2011; p. 142. [CrossRef]

23. Mayunga, J.S. Understanding and Applying the Concept of Community Disaster Resilience: A Capital-Based Approach; A draft working paper prepared for the Summer Academy for Social Vulnerability and Resilience Building: Munich, Germany, $22-28$ July 2007.

24. Arbon, P.; Steenkamp, M.; Cornell, V.; Cusack, L.; Gebbie, K. Measuring disaster resilience in communities and households: Pragmatic tools developed in Australia. Int. J. Disaster Resil. Built Environ. 2016, 7, 201-215. [CrossRef]

25. Wisner, B.; Kelman, I. Community Resilience to Disasters. In International Encyclopedia of the Social E Behavioral Sciences, 2nd ed.; Wright, J.D., Ed.; Elsevier: Amsterdam, The Netherlands, 2015; pp. 354-360. [CrossRef]

26. Fitzpatrick, T. Community disaster resilience. In Disasters and Public Health, 2nd ed.; Clements, B.W., Casani, J.A.P., Eds.; Butterworth-Heinemann: Oxford, UK, 2016; pp. 57-85.

27. Yoon, D.K.; Kang, J.E.; Brody, S.D. A measurement of community disaster resilience in Korea. J. Environ. Plan. Manag. 2015, 59, 436-460. [CrossRef]

28. Ostadtaghizadeh, A.; Ardalan, A.; Paton, D.; Khankeh, H.; Jabbari, H. Community disaster resilience: A qualitative study on Iranian concepts and indicators. Nat. Hazards 2016, 83, 1843-1861. [CrossRef]

29. Chandra, A.; Williams, M.; Plough, A.; Stayton, A.; Wells, K.B.; Horta, M.; Tang, J. Getting Actionable About Community Resilience: The Los Angeles County Community Disaster Resilience Project. Am. J. Public Health 2013, 103, 1181-1189. [CrossRef] [PubMed]

30. Sherrieb, K.; Norris, F.H.; Galea, S. Measuring Capacities for Community Resilience. Soc. Indic. Res. 2010, 99, 227-247. [CrossRef]

31. Clark-Ginsberg, A.; McCaul, B.; Bremaud, I.; Cáceres, G.; Mpanje, D.; Patel, S.; Patel, R. Practitioner approaches to measuring community resilience: The analysis of the resilience of communities to disasters toolkit. Int. J. Disaster Risk Reduct. 2020, $50,101714$. [CrossRef] [PubMed]

32. Twigg, J. Characteristics of a Disaster-Resilient Community: A Guidance Note. 2007. Benfield UCL Hazard Research Centre Website. Available online: https://www.preventionweb.net/files/2310_Characteristicsdisasterhighres.pdf (accessed on 2 June 2021).

33. Chisty, M.A.; Rahman, M.; Khan, N.A.; Alam Dola, S.E. Assessing Community Disaster Resilience in Flood-Prone Areas of Bangladesh: From a Gender Lens. Water 2022, 14, 40. [CrossRef]

34. Fenxia, Z. The community resilience measurement throughout the COVID-19 pandemic and beyond -an empirical study based on data from Shanghai, Wuhan and Chengdu. Int. J. Disaster Risk Reduct. 2022, 67, 102664. [CrossRef]

35. Cruz, N. Measuring Informal Urban Settlements' Pathway to Resilience Building. In Proceedings of the IFoU 2018: Reframing Urban Resilience Implementation: Aligning Sustainability and Resilience, Barcelona, Spain, December 2018; MDPI: Basel, Switzerland, 2018. [CrossRef]

36. Mehryar, S.; Sasson, I.; Surminski, S. Supporting urban adaptation to climate change: What role can resilience measurement tools play? Urban Clim. 2022, 41, 101047. [CrossRef]

37. Neuman, W.L. Social Research Methods: Qualitative and Quantitative Approaches, 7th ed.; Pearson: Essex, UK, 2009 ; p. 631. 
38. Flood Forecasting \& Warning Center; Processing \& Flood Forecasting Circle; Bangladesh Water Development Board. Annual Flood Report 2016. Flood Forecasting \& Warning Center Website. Available online: http://www.ffwc.gov.bd/images/annual16.pdf (accessed on 2 June 2021).

39. Tejada, J.; Punzalan, J. On the Misuse of Slovin's Formula. Philipp. Stat. 2012, 61, 129-136.

40. Chakraborty, U.; Bhat, S. The Effects of Credible Online Reviews on Brand Equity Dimensions and Its Consequence on Consumer Behavior. J. Promot. Manag. 2018, 24, 57-82. [CrossRef]

41. Creswell, J.W.; Clark, V.L.P. Designing and Conducting Mixed Methods Research, 3rd ed.; SAGE Publications Inc: Los Angeles, CA, USA, 2017.

42. Sarantakos, S. Social Research, 4th ed.; Red Globe Press: London, UK, 2013.

43. IBM SPSS Statistics, version 25; Campus licentie; IBM: Armonk, NY, USA, 2018. Available online: https://www.surfspot.nl/ibmspss-25-statistics.html (accessed on 2 June 2021).

44. Nakamura, H.; Umeki, H.; Kato, T. Importance of communication and knowledge of disasters in community-based disasterprevention meetings. Saf. Sci. 2017, 99, 235-243. [CrossRef]

45. Price-Robertson, R.; Knight, K. Natural disasters and community resilience: A framework for support. Child Family Community Australia (CFCA): Canberra, Australia, 2012. Available online: https://aifs.gov.au/cfca/sites/default/files/cfca/pubs/papers/ a141862/cfca03.pdf. (accessed on 2 June 2021).

46. Cavaye, J.; Ross, H. Community resilience and community development: What mutual opportunities arise from interactions between the two concepts? Community Dev. 2019, 50, 181-200. [CrossRef]

47. Cutter, S.; Ash, K.; Emrich, C.T. The geographies of community disaster resilience. Glob. Environ. Chang. 2014, 29, 65-77. [CrossRef]

48. Chisty, M.A.; Alam Dola, S.E.; Khan, N.A.; Rahman, M. Intersectionality, vulnerability and resilience: Why it is important to review the diversifications within groups at risk to achieve a resilient community. Contin. Resil. Rev. 2021, 3, 119-131. [CrossRef]

49. Cox, R.S.; Hamlen, M. Community Disaster Resilience and the Rural Resilience Index. Am. Behav. Sci. 2014, 59, 220-237. [CrossRef]

50. Fekete, A. Critical infrastructure cascading effects. Disaster resilience assessment for floods affecting city of Cologne and Rhein-Erft-Kreis. J. Flood Risk Manag. 2020, 13, e312600. [CrossRef]

51. Cutter, S.L.; Burton, C.G.; Emrich, C.T. Disaster Resilience Indicators for Benchmarking Baseline Conditions. J. Homel. Secur. Emerg. Manag. 2010, 7, 1-25. [CrossRef]

52. Gwimbi, P. Linking rural community livelihoods to resilience building in flood risk reduction in Zimbabwe. Jàmbá J. Disaster Risk Stud. 2009, 2, 80-89. [CrossRef]

53. Cox, R.S.; Perry, K.-M.E. Like a Fish Out of Water: Reconsidering Disaster Recovery and the Role of Place and Social Capital in Community Disaster Resilience. Am. J. Community Psychol. 2011, 48, 395-411. [CrossRef] [PubMed]

54. Boin, A.; McConnell, A. Preparing for Critical Infrastructure Breakdowns: The Limits of Crisis Management and the Need for Resilience. J. Contingencies Crisis Manag. 2007, 15, 50-59. [CrossRef]

55. Zavaleta, K.W.; Asirvatham, U.; Callies, B.; Franz, W.B.; Scanlan-Hanson, L.; Molella, R.G. Improving Community Resilience through Disaster Simulation: How Simulation-based Education Augments Emergency Management Exercises. J. Homel. Secur. Emerg. Manag. 2018, 15, 20180002. [CrossRef]

56. Ohara, M.; Nagumo, N.; Shrestha, B.B.; Sawano, H. Evidence-Based Contingency Planning to Enhance Local Resilience to Flood Disasters. In Recent Advances in Flood Risk Management; Abbot, J., Hammond, A., Eds.; IntechOpen: London, UK, 2019; pp. 39-55. [CrossRef]

57. Pfefferbaum, R.L.; Pfefferbaum, B.; Nitiéma, P.; Houston, J.B.; Van Horn, R.L. Assessing Community Resilience: An Application of the Expanded CART Survey Instrument With Affiliated Volunteer Responders. Am. Behav. Sci. 2014, 59, 181-199. [CrossRef] 